\title{
Reduction in nitrogen fertilization in Triticum sp. inoculated and co-inoculated
}

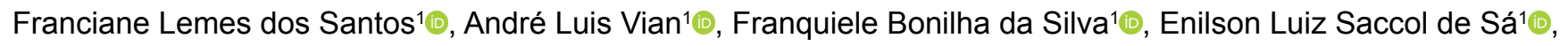

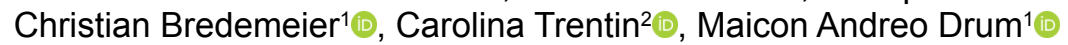

\footnotetext{
1 Universidade Federal do Rio Grande do Sul, Porto Alegre-RS, Brasil. E-mail: franciane_lemes@hotmail.com; andre.vian@ufrgs.br; franquiele_bonilha@yahoo.com.br; enilson.sa@gmail.com; bredemeier@ufrgs.br; maicon.drum@ufrgs.br

2 Universidade Passo Fundo, Passo Fundo-RS, Brasil. E-mail: carolinatrentin@live.com
}

ABSTRACT: Using techniques of inoculation and co-inoculation of plant growth-promoting rhizobacteria (PGPR) could be an alternative with great potential for the wheat agricultural market, aiming towards a higher fertilizer efficiency and a subsequent reduction in environmental impacts. The objective of this study was to evaluate the efficiency of rhizobia symbiont inoculants isolated from legumes, individually and combined with Azospirillum brasilense, in promoting the growth of the wheat crop. The experiments were performed with the cultivars BRS Parrudo and TBIO Sossego, both inoculated and co-inoculated with the rhizobia UFRGS Vp16 and UFRGS Lc348, and A. brasilense, and under nitrogen dosage levels recommended for wheat plants. Inoculation of rhizobia, isolated or combined with $A$. brasilense, promotes increases in the production of wheat grains with half of the nitrogen dose recommended in the two evaluated cultivars, standing as an economically viable and ecologically sustainable alternative for the agricultural market.

Key words: Azospirillum sp.; growth promotion; rhizobacteria; wheat; yield

\section{Redução na adubação nitrogenada em Triticum sp. inoculado e coinoculado}

RESUMO: A utilização das técnicas de inoculação e coinoculação de rizobactérias promotoras do crescimento de plantas (RPCPs) pode ser uma alternativa com grande potencial para o mercado agrícola do trigo, visando uma maior eficiência no uso de fertilizantes e consequentemente redução do impacto ambiental. $O$ objetivo deste trabalho foi avaliar a eficiência da inoculação de rizóbios simbiontes em leguminosas, isoladamente e em conjunto com Azospirillum brasilense, na promoção de crescimento da cultura do trigo. Os experimentos foram realizados com as cultivares BRS Parrudo e a TBIO Sossego, inoculadas e coinoculadas com os rizóbios UFRGS Vp16 e UFRGS Lc348, e A. brasilense, e sob níveis de doses de nitrogênio recomendadas para plantas de trigo. A inoculação de rizóbios, isoladamente ou em coinoculação com $A$. brasilense promove aumentos de produção de grãos de trigo com metade da dose de nitrogênio recomendada nas duas cultivares avaliadas, sendo uma alternativa economicamente viável e ecologicamente sustentável para o mercado agrícola.

Palavras-chave: Azospirillum sp.; promoção de crescimento; rizobactérias; trigo; produtividade 


\section{Introduction}

Wheat (Triticum aestivum L.) is among the vegetable species that are most prominent in the world economy, considered a staple food due to the diversified production of its grains derivatives (Scheuer et al., 2011). In Brazil, the production of the harvest from 2018 was of 5.5 million tons, with the South region responsible for $90 \%$ of it (Conab, 2018).

Like most grain-producing plant species, a good yield comes from the association of several factors, such as using cultivars adapted to local conditions, good soil fertility and a rigorous pest and disease management (Mumbach et al., 2017). Proper management of the nitrogen fertilization is one of the essential factors for obtaining good yields in the crop, mainly because this nutrient is absorbed in large quantities by the plants (Zagonel et al., 2002).

Nitrogen is the nutrient that most interferes in wheat production (Rodrigues et al., 2014), since it takes part in composing the organic compounds, acting in tillering and the biomass and seed production, directly influencing the yield and quality of the grains (Vogel \& Fey, 2016). Using industrial fertilizer is the main available source of nitrogen for wheat plants, with high doses of this nutrient applied in order to obtain high yield. However, plants use only $50 \%$ of the applied, with the rest lost due to leaching, ammonia volatilization, denitrification, microbial immobilization and erosion. This overuse can result in damage to the environment such as the soil acidification and waters eutrophication, as well as raising the production costs (Pinto et al., 2017).

In the perspective of a more economically viable and environmentally sustainable agricultural production, the interest in using plant growth-promoting rhizobacteria (PGPRs) has increased. These PGPRs are capable of colonizing both the surface of the roots and internal tissues of the plants, promoting their growth through the production of hormones, phosphate solubilization, greater root development, increased chlorophyll content, in addition to changing the photosynthetic activity (Hungria, 2011; Gordillo-Delgado et al., 2016; Kazi et al., 2016).

Results obtained through research with PGPRs inoculation in wheat cultivation have been promising (Mumbach et al., 2017; Pereira et al., 2017), demonstrating that this practice can supply, at least in part, the nitrogen need in plants, enabling reduced nitrogen doses. However, the agronomic feasibility of this practice in the soils from Rio Grande do Sul still needs to be better evaluated, requiring more scientific information about the interaction of PGPRs (mainly rhizobia, symbionts in legumes) with the used cultivars in the state crops.

Thereby, the objective of the present study was to evaluate the potential of inoculation and co-inoculation of two strains of rhizobia and commercial inoculant containing strains of Azospirillum brasilense bacteria, in the development and yield of grain from the wheat cultivars TBIO Sossego and BRS Parrudo.

\section{Materials and Methods}

The study was conducted in the field during the agricultural harvest of 2016 in the Agricultural Experiment Station of the Federal University of Rio Grande do Sul (EEA/UFRGS), in the municipality of Eldorado do Sul-RS (300'S; 513' W). The EEA/UFRGS is located in the physiographic region of the Central Depression of Rio Grande do Sul (RS), at an average altitude of 46 meters above the sea level. Regarding wheat production, the region classification is as a Homogeneous Region for the Adaptation of Cultivars 2. The climate is subtropical with a hot humid summer, from the Cfa-type, according to the Koppen classification.

The experimental area soil, belonging to the São Jerônimo mapping unit, is characterized as a typical Dysthropic Red Argisol (Ultisol). Its chemical characteristics $(0-0.20 \mathrm{~m})$ prior to setting up the experiments were the following: Clay: $27 \%$; $\mathrm{pH}\left(\mathrm{H}_{2} \mathrm{O}\right)$ : 5.6; P: $20 \mathrm{mg} \mathrm{dm}^{-3}$; $\mathrm{K}: 165 \mathrm{mg} \mathrm{dm}^{-3}$; Ca: $4.3 \mathrm{cmol}_{\mathrm{c}}$ dm ${ }^{-3}$; Mg: $1.9 \mathrm{cmol}_{\mathrm{c}} \mathrm{dm}^{-3}$; OM: $21 \mathrm{~g} \mathrm{~kg}^{-1}$ e CEC: $6.62 \mathrm{cmol}_{\mathrm{c}} \mathrm{dm}^{-}$ ${ }^{3}$. Precipitation in the year of the experiment was of $1690 \mathrm{~mm}$, with the average monthly temperature ranging from 14 to 30 o $\mathrm{C}$, between the coldest and the warmest months.

Sowing was performed in June 2016, with each plot consisting of 10 planting rows three meters long, spaced 0.18 $\mathrm{m}$ apart each other. The used cultivars were BRS Parrudo and TBIO Sossego, both of medium cycle (130-135 days), mediumsize and recommended for cultivation in the studied region, with the experiment conducted under dry conditions.

For each cultivar, an experiment was set up in a randomized block design, with twelve treatments and four replicates, totaling 48 experimental units. Sowing fertilization was composed by $150 \mathrm{~kg} \mathrm{ha}^{-1}$ of $\mathrm{P}_{2} \mathrm{O}_{5}$ and $150 \mathrm{~kg} \mathrm{ha}^{-1}$ of $\mathrm{K}_{2} \mathrm{O}$, and the top dressing fertilization, which differentiate the treatments, was of $50 \mathrm{kgha}^{-1}$ (50\% dose) and $100 \mathrm{~kg} \mathrm{ha}^{-1}$ (100\% dose) of nitrogen (recommended and described by CQFS RS/SC, 2004), split into two applications, at the stages V2 $\left(20 \mathrm{~kg} \mathrm{ha}^{-1}\right.$ and $40 \mathrm{~kg}$ $\left.\mathrm{ha}^{-1}\right)$ and V6 (30 kg ha-1 and $\left.60 \mathrm{~kg} \mathrm{ha}^{-1}\right)$. Crop treatments were performed according to technical indications for the wheat crop (Reunion of the Brazilian Wheat and Triticale Research Commission, 2017), requiring two fungicides applications to control the head blight and leaf rust diseases.

The used rhizobacteria were the rhizobia UFRGS Vp16 (Burkholderia sp.), isolated from white clover (Trifolium repens) by Alves et al. (2012), and UFRGS Lc348 (Mesorhizobium sp.), isolated from plants of common bird's-foot trefoil (Lotus corniculatus) by Frizzo (2007), both belonging to the Collection of Rhizobia Strains from UFRGS, and the $A$. brasilense (commercial product containing the strains AbV5 and AbV6).

The 12 tested treatments were the following: no inoculation + fertilization with $50 \% \mathrm{~N}$; no inoculation + fertilization with $100 \% \mathrm{~N}$; inoculation with UFRGS Vp16 + fertilization with $50 \% \mathrm{~N}$; inoculation with UFRGS Vp16 + fertilization with $100 \%$ $\mathrm{N}$; inoculation with UFRGS Lc348 + fertilization with $50 \%$ $\mathrm{N}$; inoculation with UFRGS Lc348 + fertilization with $100 \%$ $\mathrm{N}$; inoculation with $A$. brasilense + fertilization with $50 \% \mathrm{~N}$; inoculation with $A$. brasilense + fertilization with $100 \% \mathrm{~N}$; co- 
inoculation with UFRGS Vp16 + A. brasilense + fertilization with $50 \% \mathrm{~N}$; co-inoculation with UFRGS Vp16 + A. brasilense + fertilization with $100 \% \mathrm{~N}$; co-inoculation with UFRGS Lc348 + A. brasilense + fertilization with $50 \% \mathrm{~N}$; co-inoculation with UFRGS Lc348 + A. brasilense + fertilization with 100\% N.

For producing bacterial inoculum, the rhizobia (UFRGS Vp16 and UFRGS Lc348) were inoculated, in an isolate manner, in $1000 \mathrm{ml}$ Erlenmeyer-type flasks containing the Liquid Yeast Mannitol (YM) culture medium at pH 6.8 (Vincent, 1970). The Erlenmeyer flasks were placed in an incubator with $120 \mathrm{rpm}$ orbital shaking for six days at $28^{\circ} \mathrm{C}$. The bacteria inoculation was by spraying when the plants were in stages V2-V3. For the inoculated treatments, the used was a $200 \mathrm{ml} \mathrm{ha}^{-1}$ dose

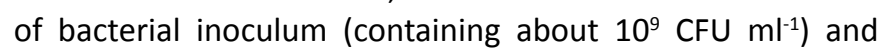
$100 \mathrm{ml} \mathrm{ha}^{-1}$ of the commercial product (in the concentration guaranteed by the manufacturer of $2.0 \times 10^{8}$, containing the strains AbV5 and Abv6 of $A$. brasilense), diluted in 10 liters of water for spraying on the plants.

The eight central rows, each one with two meters in length $\left(2.88 \mathrm{~m}^{2}\right)$, were considered as the useful area of the plot, and were evaluated for: (i) shoot dry matter in the flowering stage; (ii) number of ears per square meter; (iii) hectoliter weight (iv) weight of 1000 grains and (v) grain yield.

The yield component and grain yield data were subjected to analysis of variance by the Scott-Knott test at a significance level of $10 \%$, aided by the statistical program SISVAR (Ferreira, 2000).

\section{Results and Discussion}

The number of ears per square meter was significant $(p<0.10)$ for the TBIO Sossego cultivar, ranging from 458.33 (treatment $\mathrm{N} / 2+\mathrm{Vp} 16$ ) to 598.61 (treatment $\mathrm{N}+$ Azospirillum). For the BRS Parrudo cultivar, the number of ears per square meter and the weight of 1000 grains showed differences between treatments $(p<0.10)$. The number of ears per square meter ranged from 359.72 (treatment $N$ $+\mathrm{Vp16}$ ) to 454.17 (treatment $\mathrm{N}+$ Lc348). For the weight of 1000 grains component, the inoculated or co-inoculated treatments had a weight equivalent to the control treatment with the $100 \%$ nitrogen dose, emphasizing the treatments that received half the nitrogen dose and the co-inoculation technique was applied: N/2 + Azospirillum + Vp16 (36.99 g) and N/2 + Azospirillum + Lc348 (36.98 g) (Table 1).

Regardless of the cultivar, a $50 \%$ reduction in the nitrogen dose reduced the number of ears per square meter in most treatments that received the inoculation or co-inoculation of rhizobia and Azospirillum. A similar result was reported in a study that worked with ways of applying nitrogen and Azospirillum (Mumbach et al., 2017). On the other hand, it was also reported that, differently from the results of this study, the reduced nitrogen dose, when associated with inoculation, did not result in a reduced number of ears in wheat (Rosário, 2013).

A noteworthy important characteristic is that the number of ears per square meter is variable between cultivars and this component is indirectly related to grain yield, since these ears can abort during the development cycle. In other words, a greater number of ears per square meter may not mean an increased grain yield (Valério et al., 2008), as it can be seen in this study.

Regarding the weight of 1000 grains of the BRS Parrudo cultivar, Table 1 shows that the inoculated or co-inoculated treatments associated with $50 \%$ of the nitrogen dose $(50 \mathrm{~kg}$ $\mathrm{ha}^{-1}$ ) had grain weight equivalent to the control treatment with $100 \%$ of nitrogen fertilization (with the exception of treatment $\mathrm{N} / 2+$ Azospirillum). These results suggest that inoculated PGPRs allowed the plants to allocate photoassimilates for later grain filling. Pereira et al. (2017), evaluating doses of nitrogen and Azospirillum, have already verified the benefits of PGPR inoculation on the weight of wheat grains.

Wheat has a high capacity in compensating for the lack or excess of one yield component by modifying the other ones (Holen et al., 2001). Such modification, depending on the cultivar, environment, management and the interaction between these factors, may be sufficient in maximizing the productive potential (Valério et al., 2008). When analyzing the yield components results of the present study, it is possible to observe this compensatory effect of the cultivars, because when the treatments had a lower number of ear per square meter, there was an increase in the weight of the grains.

Regarding grain yield, there was a difference $(p<0.10)$ between treatments in the two evaluated cultivars (Table 2 ). For the TBIO Sossego cultivar, wheat production ranged from $3.2 \mathrm{t} \mathrm{ha}^{-1}$ (control treatment with $50 \%$ nitrogen dose) to $4.3 \mathrm{t}$ ha $^{-1}$ (treatment inoculated with UFRGS Lc348 + 100\% nitrogen). In the BRS Parrudo cultivar, production varied between $2.6 \mathrm{t}$ $\mathrm{ha}^{-1}$ in the control treatment with $50 \%$ of the nitrogen dose, and $3.6 \mathrm{t} \mathrm{ha}^{-1}$ in the co-inoculated treatment with rhizobia UFRGS Lc348 + Azospirillum $+100 \%$ of the nitrogen dose.

Except for the $\mathrm{N} / 2+$ Azospirillum treatment for the TBIO Sossego cultivar, and the N/2+Azospirillum and N/2+ Azospirillum + Lc348 treatments for the BRS Parrudo cultivar, using half the dose of nitrogen $\left(50 \mathrm{~kg} \mathrm{ha}^{-1}\right)$ associated with the inoculation or co-inoculation of PGPRs showed similar yield to the plots that only received $100 \%$ nitrogen. Positive results with the reduced nitrogen dosage and the maintenance of yield were also found in studies by Rosário (2013), who did not obtain significant difference when evaluating wheat plants associated with the $A$. brasilense bacterium and reduced nitrogen fertilization,.

Using rhizobia UFRGS Vp16 and UFRGS Lc348, and Azospirillum did not increase the grain yield when compared to the control treatment with the $100 \%$ nitrogen dose, but the yield was maintained in inoculated plants, allowing a reduction of $50 \%$ of the nitrogen fertilizer. Similar results were found in other studies with grain-producing plants, when the authors worked with different levels of nitrogen fertilization and inoculation with Azospirillum (Rosário, 2013; Pereira et al., 2017; Mumbach et al., 2017).

However, reports of inconsistent results on the PGPRs efficiency in both promoting growth and increasing plant yield are common in the literature (Oliveira et al., 2015). Studies 
Table 1. Shoot dry matter, yield components (number of ears per square meter and weight of 1000 grains) and hectolitric weight of wheat plants inoculated and co-inoculated with plant growth-promoting rhizobacteria.

\begin{tabular}{|c|c|c|c|c|}
\hline Treatment & $\begin{array}{c}\text { Shoot dry matter } \\
\left(\mathrm{kg} \mathrm{ha}^{-1}\right)\end{array}$ & Ear $/ \mathrm{m}^{2}$ & $\begin{array}{l}\text { Weight of } 1000 \text { grains } \\
\text { (g) }\end{array}$ & $\begin{array}{c}\mathrm{HW} \\
\left(\mathrm{kg} \mathrm{hl}^{-1}\right) \\
\end{array}$ \\
\hline \multicolumn{5}{|c|}{ TBIO Sossego } \\
\hline Control N/2 (50 kg) & $4262.59 \mathrm{a}$ & $575.00 \mathrm{a}$ & $34.33 \mathrm{a}$ & $76.33 \mathrm{a}$ \\
\hline $\mathrm{N} / 2+\mathrm{Vp} 16$ & $4891.85 \mathrm{a}$ & $458.33 b$ & $35.10 \mathrm{a}$ & $77.00 \mathrm{a}$ \\
\hline $\mathrm{N}+\mathrm{Vp} 16$ & $4987.78 \mathrm{a}$ & $575.00 \mathrm{a}$ & $35.91 \mathrm{a}$ & $76.24 \mathrm{a}$ \\
\hline$N / 2+L C 348$ & $5142.22 \mathrm{a}$ & $506.94 b$ & $35.56 \mathrm{a}$ & $76.35 \mathrm{a}$ \\
\hline $\mathrm{N} / 2+$ Azosp. & $4739.63 \mathrm{a}$ & $515.28 b$ & $34.28 \mathrm{a}$ & $76.99 \mathrm{a}$ \\
\hline $\mathrm{N}+$ Azosp & $5392.22 \mathrm{a}$ & $597.22 \mathrm{a}$ & $36.43 \mathrm{a}$ & $76.62 \mathrm{a}$ \\
\hline $\mathrm{N} / 2+$ Azosp. + Vp16 & $4888.52 \mathrm{a}$ & $469.44 b$ & $35.24 \mathrm{a}$ & $77.12 \mathrm{a}$ \\
\hline $\mathrm{N}+$ Azosp. $+\mathrm{Vp} 16$ & $4784.44 \mathrm{a}$ & $513.89 b$ & $36.25 \mathrm{a}$ & $76.48 \mathrm{a}$ \\
\hline $\mathrm{N} / 2+$ Azosp. $+\mathrm{Lc} 348$ & $4811.85 \mathrm{a}$ & $491.67 b$ & $36.95 \mathrm{a}$ & $76.94 \mathrm{a}$ \\
\hline $\mathrm{N}+$ Azosp. $+\mathrm{Lc} 348$ & $5261.48 \mathrm{a}$ & 580.56 a & $36.80 \mathrm{a}$ & $76.53 a$ \\
\hline Control N (100 kg) & $5613.33 \mathrm{a}$ & $425.56 \mathrm{a}$ & $35.85 \mathrm{a}$ & $76.69 \mathrm{a}$ \\
\hline $\mathrm{N} / 2+\mathrm{Vp} 16$ & $4494.07 \mathrm{a}$ & $384.72 b$ & $36.86 \mathrm{a}$ & $77.60 \mathrm{a}$ \\
\hline$N+V p 16$ & $5651.48 \mathrm{a}$ & $359.72 b$ & $36.78 \mathrm{a}$ & $76.97 \mathrm{a}$ \\
\hline$N / 2+L c 348$ & $4794.07 \mathrm{a}$ & 427.78 a & $35.94 \mathrm{a}$ & $77.87 a$ \\
\hline$N+\operatorname{Lc3} 48$ & $4760.00 \mathrm{a}$ & 454.17 a & $36.09 a$ & $76.57 \mathrm{a}$ \\
\hline $\mathrm{N} / 2+$ Azosp. & $4968.15 \mathrm{a}$ & $390.28 b$ & $34.78 \mathrm{~b}$ & $77.16 \mathrm{a}$ \\
\hline $\mathrm{N}+$ Azosp. & $5250.74 a$ & $448.61 \mathrm{a}$ & $36.67 \mathrm{a}$ & $77.51 \mathrm{a}$ \\
\hline $\mathrm{N} / 2+$ Azosp. $+\mathrm{Vp} 16$ & $5118.52 \mathrm{a}$ & $361.50 \mathrm{~b}$ & $36.99 \mathrm{a}$ & $77.37 \mathrm{a}$ \\
\hline $\mathrm{N}+$ Azosp. + Vp16 & $5414.44 a$ & 426.39 a & $36.42 \mathrm{a}$ & $76.84 \mathrm{a}$ \\
\hline $\mathrm{N} / 2+$ Azosp. + Lc348 & $4710.37 a$ & $387.50 \mathrm{~b}$ & $36.98 a$ & $77.28 \mathrm{a}$ \\
\hline $\mathrm{N}+$ Azosp. $+\mathrm{Lc} 348$ & $5298.89 a$ & 429.17 a & $36.85 a$ & $76.00 \mathrm{a}$ \\
\hline CV (\%) & 7.73 & 6.21 & 9.89 & 5.17 \\
\hline
\end{tabular}

Means followed by the same letter in the row do not differentiate from each other by the Scott-Knott test at the significance level of $10 \%$. N/2 = $50 \mathrm{~kg}$ of $\mathrm{N} ; \mathrm{N}=100 \mathrm{~kg}$ of $\mathrm{N} ; A z o s p$. = Azospirillum brasilense.

Table 2. Yield of what grains in function of the inoculation and co-inoculation with rhizobia and Azospirillum brasilense.

\begin{tabular}{lcc}
\hline \multirow{2}{*}{ Treatment } & \multicolumn{2}{c}{ Grain yield (kg ha-1) } \\
\cline { 2 - 3 } & TBIO Sossego & BRS Parrudo \\
\hline Control N/2 (50 kg) & $3229.91 \mathrm{~b}$ & $2695.78 \mathrm{~b}$ \\
Control N (100 kg) & $4240.51 \mathrm{a}$ & $3524.51 \mathrm{a}$ \\
$\mathrm{N} / 2+$ Vp16 & $3801.53 \mathrm{a}$ & $3047.81 \mathrm{a}$ \\
$\mathrm{N}+$ Vp16 & $4116.07 \mathrm{a}$ & $3526.42 \mathrm{a}$ \\
$\mathrm{N} / 2+$ Lc348 & $3934.42 \mathrm{a}$ & $3045.89 \mathrm{a}$ \\
$\mathrm{N}+$ Lc348 & $4324.75 \mathrm{a}$ & $3535.99 \mathrm{a}$ \\
$\mathrm{N} / 2+$ Azosp. & $3488.13 \mathrm{~b}$ & $2816.16 \mathrm{~b}$ \\
$\mathrm{~N}+$ Azosp. & $4317.09 \mathrm{a}$ & $3292.86 \mathrm{a}$ \\
$\mathrm{N} / 2+$ Azosp. + Vp16 & $3965.05 \mathrm{a}$ & $3107.15 \mathrm{a}$ \\
$\mathrm{N}+$ Azosp. + Vp16 & $4083.53 \mathrm{a}$ & $3518.76 \mathrm{a}$ \\
$\mathrm{N} / 2+$ Azosp.+ Lc348 & $4051.20 \mathrm{a}$ & $2800.84 \mathrm{~b}$ \\
$\mathrm{~N}+$ Azosp. + Lc348 & $4240.51 \mathrm{a}$ & $3601.08 \mathrm{a}$ \\
CV (\%) & 12.54 & 14.26 \\
\hline
\end{tabular}

Means followed by the same letter in the row do not differentiate from each other by the Scott-Knott test at the significance level of $10 \% . \mathrm{N} / 2=50 \mathrm{~kg}$ of N; N $=100 \mathrm{~kg}$ of N; Azosp. = Azospirillum brasilense.

indicate that the inoculation success is directly related to the interaction between plant genotypes and bacterial isolates, as well as other related factors such as the environment (Pandolfo et al., 2015).

In the experimental conditions of this study, the TBIO Sossego cultivar was more productive than the BRS Parrudo cultivar. Considering the mean yield (10 years) of wheat crops in the state of Rio Grande do Sul (2089.00 kg ha-1) (Conab, 2017), the TBIO Sossego cultivar yield was up to $52 \%$ higher than the mean, while the BRS Parrudo cultivar was up to $41 \%$ higher.

Due to the high existing costs in relation to nitrogen fertilizers, using alternative sources in the partial replacement of nitrogen fertilization can become an economically viable option (Hungria, 2011), able to promote the wheat crop yield maintenance. Thus, the results found in this study show that using PGPR inoculation or co-inoculation allows reducing half the amount of the used nitrogen fertilizer, with no losses in grain production, representing an important saving in Brazilian agriculture.

\section{Conclusions}

Inoculation and co-inoculation of the rhizobia UFRGSVP16 and UFRGS Lc348, as well as of the A. brasilense, only interferes in the yield component of number of ears per square meter when cultivating TBIO Sossego, while for BRS Parrudo, the inoculation and co-inoculation change the number of ears per square meter and weight of 1000 grains.

Inoculating rhizobia, isolated or in co-co-inoculation with A. brasilense, maintains the wheat grains production with only $50 \%$ of the nitrogen dose. 


\section{Acknowledgements}

To the Brazilian National Council for Scientific and Technological Development (CNPq) for granting the doctoral scholarship to the first author.

\section{Literature Cited}

Alves, J.B; Sá, E.L.S.; Muniz, A.W. Seleção de rizóbios para o Trifolium repens em condições de solo alagado. Biotemas, v.25, n.1, p.3945, 2012. https://doi.org/10.5007/2175-7925.2012v25n1p39.

Companhia Nacional de Abastecimento - Conab. Acompanhamento da safra brasileira de grãos. v.6, safra 2018/2019, n.2 - segundo levantamento, p.1-138, 2018. 138p. https://www.conab.gov.br/infoagro/safras/graos/boletim-da-safra-de-graos/item/download/22835_ a4e21f191899c30a7c7c4abf4ac59979. 29 Mar. 2019.

Companhia Nacional de Abastecimento - Conab. Acompanhamento da safra brasileira de grãos. v.3, safra 2016/2017, n.1, primeiro levantamento, p.1-162, 2017. 162p. https://www.conab.gov.br/infoagro/safras/graos/boletim-da-safra-de-graos/item/download/1306_ ff331936bf7c757774177d12c441b3b0. 29 Mar. 2019.

Comissão de Química e Fertilidade do Solo dos Estados do Rio Grande do Sul e Santa Catarina - CQFS-RS/SC. Manual de adubação e calagem para os Estados do Rio Grande do Sul e Santa Catarina. Porto Alegre: SBCSNRS; Embrapa; CNPT, 2004. 400p.

Ferreira, D.F. Manual do sistema Sisvar para análises estatísticas. Lavras: Universidade Federal de Lavras, 2000. 66 p.

Frizzo, M.L.S. Isolamento de rizóbios nativos para Lotus corniculatus e L. uliginosus em solos do Rio Grande do Sul. Porto Alegre: Universidade Federal do Rio Grande do Sul, 2007.68p. Dissertação Mestrado. http://www.dominiopublico.gov.br/pesquisa/ DetalheObraForm.do?select_action=\&co_obra=116471. 10 Mar. 2019.

Gordillo-Delgado, F.; Marín, E.; Calderón, A. Effect of Azospirillum brasilense and Burkholderia unamae bacteria on maize photosynthetic activity evaluated using the photoacoustic technique. International Journal of Thermophysics, v.37, n.9, p.111, 2016. https://doi.org/10.1007/s10765-016-2101-x.

Holen, D.L.; Bruckner, P.L.; Martin, J. M.; Carlson, G.R.; Wichman, D.M.; Berg, J.E. Response of winter wheat to simulated stand reduction. Agronomy Journal, v.93, n.1, p.364-370, 2001. https:// doi.org/10.2134/agronj2001.932364x.

Hungria, M. Inoculação com Azospirillum brasiliense: inovação em rendimento a baixo custo. Londrina: Embrapa Soja, 2011. 36p. (Embrapa Soja. Documentos, 325). http://ainfo.cnptia.embrapa. br/digital/bitstream/item/29560/1/DOC325.2011.pdf. 19 Mar. 2019.

Kazi, N.; Deaker, R.; Wilson, N.; Muhammad, K.; Trethowan, R. The response of wheat genotypes to inoculation with Azospirillum brasilense in the field. Field Crops Research, v.196, p.368-378, 2016. https://doi.org/10.1016/j.fcr.2016.07.012.

Mumbach, G.L.; Kotowski, I.E.; Schneider, F.J.A.; Mallmann, M.S.; Bonfada, E. B.;Portela, V.O.; Kaiser, D.R. Resposta da inoculação com Azospirillum brasilense nas culturas de trigo e de milho safrinha. Scientia Agraria, v.18, n.2, p.97-103, 2017. https://doi. org/10.5380/rsa.v18i2.51475.
Oliveira, M.A; Zucareli, C.; Ferreira, A.S.; Domingues, A.R.; Spolaor, L.T.; Neves, C. S.V. Adubação fosfatada associada à inoculação com Pseudomonas fluorescens no desempenho agronómico do milho. Revista de Ciências Agrárias, v.38, n.1, p. 18-25, 2015. URI: http:// www.scielo.mec.pt/scielo.php?script=sci_arttext\&pid=S0871018X2015000100004\&Ing=pt\&nrm=iso. 19 Mar. 2019.

Pandolfo, C.M.; Vogt, G.A.; Balbinot Júnior, A.A.; Gallotti, G.J.M.; Zoldan, S.R. Desempenho de milho inoculado com Azospirillum brasilense associado a doses de nitrogênio em cobertura. Revista Agropecuária Catarinense, v.27, n.3, p.94-99, 2015. http:// ainfo.cnptia.embrapa.br/digital/bitstream/item/29560/1/ DOC325.2011.pdf. 10 Mar. 2019.

Pereira, L.C.; Piana, S.C.; Braccini, A.L.; Garcia, M.M.; Ferri, G.C.; Felber, P.H.; Marteli, D.C.V.; Bianchessi, P.A.; Dametto, Igor B. Rendimento do trigo (Triticum aestivum) em resposta a diferentes modos de inoculação com Azospirillum brasilense. Revista de Ciências Agrárias, v.40, n.1, p.105-113, 2017. https://doi.org/10.19084/RCA16089.

Pinto, V.M.; Bruno, I.P.; Lier, Q.J.V.; Dourado Neto, D.; Reichardt, K. Uso excessivo de nitrogênio gera perda monetária para cafeicultores do cerrado baiano. Coffee Science, v.12, n.2, p.176-186. 2017. http:// www.sbicafe.ufv.br:80/handle/123456789/8641. 19 Mar. 2019.

Reunião da Comissão Brasileira de Pesquisa de Trigo e Triticale, 10., 2016, Londrina. Informações técnicas para trigo e triticale: safra 2017. Londrina: Embrapa, 2017. 240 p.

Rodrigues, L.F.O.S.; Guimarães, V.F.; Silva, M.B.; Pinto Junior, A.S.; Klein, J.; Costa, A.C.P.R. Características agronômicas do trigo em função de Azospirillum brasilense, ácidos húmicos e nitrogênio em casa de vegetação. Revista Brasileira de Engenharia Agrícola e Ambiental, v.18, n.1, p.31-37. 2014. https://doi.org/10.1590/ S1415-43662014000100005.

Rosário, J.G. Inoculação com Azospirillum brasilense associada à redução na adubação nitrogenada de cobertura em cultivares de trigo. Guarapuava: Universidade Estadual do Centro-Oeste, 2013. 85p. Dissertação Mestrado.http://www.unicentroagronomia.com/ destino_arquivo/dissertacao_jeronimo_gadens.pdf. 22 Mar. 2019.

Scheuer, P.M.; Francisco, A.; Miranda, M.Z.; Ogliari, P.J.; Torres, G.; Limberger, V.; Montenegro, F.M.; Ruffi, C.R.; Biondi, S. Characterization of Brazilian wheat cultivars for specific technological applications. Food Science and Technology, v.31, n.3, p.816-826, 2011. https://doi.org/10.1590/S0101-20612011000300041.

Valério, I.P.; Carvalho, F.I.F.; Oliveira, A.C.; Machado, A.A.; Benin, G.; Scheeren, P.L.; Souza, V.Q.; Hartwig, I. Desenvolvimento de afilhos e componentes do rendimento em genótipos de trigo sob diferentes densidades de semeadura. Pesquisa Agropecuária Brasileira, v.43, n.3, p.319-326, 2008. https://doi.org/10.1590/ S0100-204X2008000300005.

Vincent, J.M. A manual for the practical study of root nodule bacteria. London: International Biological Programme, 1970. 164 p.

Vogel, G.F.; Fey, R. Estímulo do potencial germinativo e fisiológico de centeio e triticale por Azospirillum brasilense, submetidos ao tratamento químico de sementes. Scientia Agraria Paranaensis, v.15, n.4, p.493-498, 2016. https://doi.org/10.18188/19831471/sap.v15n4p493-498.

Zagonel, J.; Venancio, W.S.; Kunz, R.P.; Tanamati, H. Doses de nitrogênio e densidade de plantas com e sem um regulador de crescimento afetando o trigo, cultivar OR-1. Ciência Rural, v.32, n.1, p.25-29, 2002. https://doi.org/10.1590/S010384782002000100005 